https://doi.org/10.15407/ujpe63.10.912

V.YU. KUDRYA,${ }^{1}$ V.M. YASHCHUK, ${ }^{1}$ A.P. NAUMENKO,${ }^{1}$ Y. MELY,${ }^{2}$ T.V. UDOD,${ }^{1,2}$ YU.S. KREMINSKA ${ }^{1}$

1 Taras Shevchenko National University of Kyiv

(64/13, Volodymyrs'ka Str., Kyiv 01601, Ukraine)

2 Laboratoire de Bioimagerie et Pathologies, Faculte de Pharmacie, UMR 7021 CNRS,

Universite de Strasbourg

(74, route du Rhin, 67401 Illkirch, France)

\title{
SPECTRAL PROPERTIES
}

OF SINGLE-STRANDED VIRAL DNA FRAGMENT

\begin{abstract}
This article presented the results of investigations of the optical absorption (at $300 \mathrm{~K})$, and steady-state and time-resolved luminescence (at $78 \mathrm{~K}$ ) of (-)PBS and $(+) P B S$ oligonucleotides. (-)PBS is the DNA form of the minus primer binding site (5'GTCCCTGTTCGGGCGCCA3') of the human immunodeficiency virus type 1 (HIV-1) genome, and (+)PBS ( $\left.3^{\prime} C A G G G A C A A G C C C G C G G T 5^{\prime}\right)$ is its complementary sequence [1, 2]. The optical absorption spectra of $(-) P B S$ and $(+) P B S$ do not coincide with the correspondent equimolar sums of the spectra of nucleotides that are in their composition. The difference between them at $295 \mathrm{~nm}$ is related to the existence of some stable complex between bases (possibly, G-complexes). The fluorescence spectral bands of $(-) P B S$ and $(+) P B S$ are close to each other and to the band of oligonucleotide investigated by us in [5-7]. In our opinion, the ()PBS and (+)PBS bands are connected possibly with the fluorescence of some complexes that are manifested in the absorption. The phosphorescence spectral bands of $(-) P B S$ and $(+) P B S$ are close to each other and to the band of $d A M P$ (in the wavelength interval 370-470 $\mathrm{nm}$ ). The difference between the (-)PBS/(+)PBS and dAMP phosphorescence spectra (at $530 \mathrm{~nm})$ is associated with an unknown center (possibly, G-complexes). Thus, the main centers of the triplet excitation capturing in (-)PBS and $(+) P B S$ are A-bases and centers of an unknown nature.

Ke ywords: G-quadruplex, primary binding site of HIV-1 genome, DNA, fluorescence, phosphorescence, singlet and triplet electronic excitations.
\end{abstract}

\section{Introduction}

Deoxyribonucleic acids (DNA) are the most important molecules of living cells and DNA viruses. The knowledge of the electronic processes in these macromolecules (especially, the behavior of singlet and triplet electronic excitations, the nature of capturing centers of both these excitations) can be used for numerous applications including the development of new effective drugs. Herein, the spectral properties of (-)PBS, the DNA form of the minus primer binding site (5'GTCCCTGTTCGGGCGCCA3') of the human immunodeficiency virus type 1 $(\mathrm{HIV}-1)$ genome and its complementary $(+) \mathrm{PBS}$ (3'CAGGGACAAGCCCGCGGT5') sequence [1]

(C) V.YU. KUDRYA, V.M. YASHCHUK,

A.P. NAUMENKO, Y. MELY, T.V. UDOD,

YU.S. KREMINSKA, 2018

912 were studied at $78 \mathrm{~K}$ firstly. At low temperature, the fluorescence and phosphorescence of oligonucleotides possess a much higher quantum yield comparing with that at room temperature and can be studied in detail. (-)PBS is an 18-mer stem-loop oligonucleotide of the well-known structure [1]. Together with its complementary $(+)$ PBS sequence, it is involved in the viral DNA synthesis [2]. The first main goal of our investigations is the identification of the absorbing, fluorescent and phosphorescent centers in $(-)$ PBS and (+)PBS. On the other hand, it is known [3-7] that the capturing centers of the triplet excitation in DNA are AT-sequences. Recently, we showed that this AT-complex is formed by neighbor A- and T-chromophores from the same strand (not from A- and T-complementary chromophores of the different strands) [5-7]. (-)PBS and (+)PBS contain both of these nucleotides ( $\mathrm{A}$ and $\mathrm{T}$ ) but

ISSN 2071-0194. Ukr. J. Phys. 2018. Vol. 63, No. 10 
separately; there are no AT-sequences. In addition, the probability of a complex binding between $\mathrm{A}$ and $\mathrm{T}$, which are situated at opposite ends of the strand, is quite low. Taking this into account, the second main goal of our investigations is the study of the possibility for AT-complexes to be created, when Aand T-chromophores are separated.

\section{Methods}

The powders of (-)PBS and (+)PBS were synthesized and purified by reverse-phase HPLC by IBA GmbH Nucleic Acids Product Supply. Samples of (-)PBS and $(+)$ PBS were prepared at the Faculty of Physics of Kyiv University, by using a TRIS-HCl buffer as the solvent with concentration $C=2 \times 10^{-4} \mathrm{M}$. Spectral measurements were carried out in Faculty of Physics of Kyiv University. Optical absorption spectra were obtained at $300 \mathrm{~K}$, by using a spectrophotometer Cary 60 (Agilent Tech., Inc.) in standard quartz cuvettes. Fluorescence and phosphorescence spectra were obtained at $78 \mathrm{~K}$ by using a fluorescent spectrophotometer Cary Eclipse (Varian, Australia). The experimental errors of wavelengths and intensities were standard for these equipments.

\section{Results and Discussions}

\subsection{Optical absorption}

The optical absorption spectrum of $(+)$ PBS (Fig. 1, line 1) differs to some extent from the equimolar sum of the corresponding spectra (Fig. 1, line 2) of deoxyribonucleotides (in the ratio $\mathrm{A}: \mathrm{G}: \mathrm{C}: \mathrm{T}=4: 7: 6: 1)$ that are in the composition of $(+)$ PBS oligonucleotide. The difference between them (Fig. 1, line 3, "difference") at $\lambda=295 \mathrm{~nm}$ is likely associated with the existence of G-complexes (possibly, G-quadruplexes or G-intermediates) [5, $6]$. As for $(+) \mathrm{PBS}$, the optical absorption spectrum of (-)PBS differs to some extent from the equimolar sum of the corresponding spectra of deoxyribonucleotides (in the ratio $\mathrm{A}: \mathrm{G}: \mathrm{C}: \mathrm{T}=1: 6: 7: 4$ ) that are in the composition of (-)PBS oligonucleotide. The difference between them (the band at $\lambda=295 \mathrm{~nm}$ ) is associated with the existence of G-complexes too [5, 6 . The "difference" bands were obtained by the subtraction of the equimolar sums from the corresponding spectra of oligonucleotides.

ISSN 2071-0194. Ukr. J. Phys. 2018. Vol. 63, No. 10

\subsection{Fluorescence}

The fluorescence spectral bands of (-)PBS and $(+) \mathrm{PBS}$ at $T=78 \mathrm{~K}$ (Fig. 2) are close to each other, as well as to the band of oligunucleotide Tel22 investigated by us earlier [5-7]. They do not co-

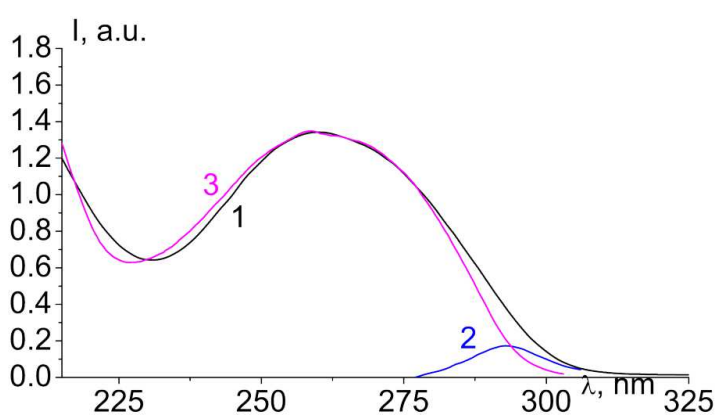

Fig. 1. The optical absorption spectra of $(+) \operatorname{PBS}(1)$, "difference" (2), and equimolar sum of the spectra of deoxyribonucleotides (in the ratio $\mathrm{A}: \mathrm{G}: \mathrm{C}: \mathrm{T}=4: 7: 6: 1$ ) that are in the composition of $(+) \mathrm{PBS}(3)$

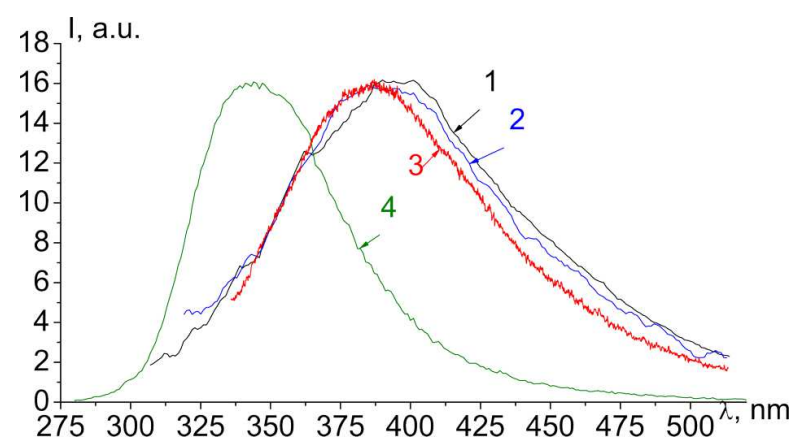

Fig. 2. The fluorescence spectra $(T=78 \mathrm{~K})$ : (-)PBS (1), $(+)$ PBS (2), Tel-22 (3), dAMP (4). $\lambda_{\text {ex }}=260 \mathrm{~nm}$ (excluding Tel-22, where $\lambda_{\text {ex }}=310 \mathrm{~nm}$ )

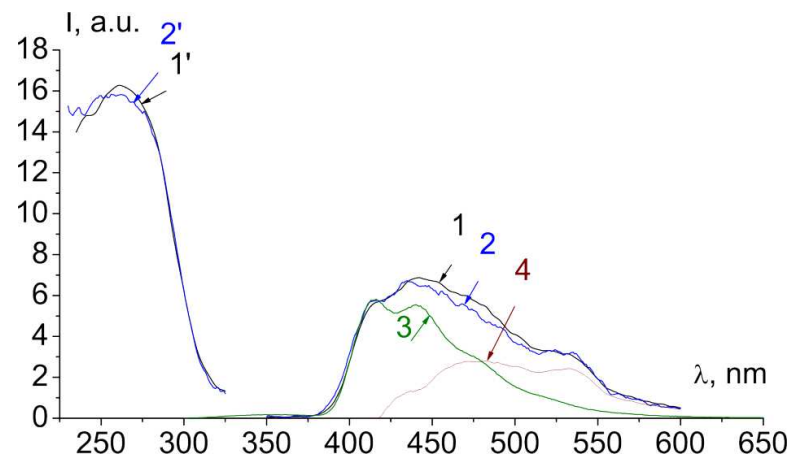

Fig. 3. The phosphorescence emission (1-4) and excitation $\left(1^{\prime}, 2^{\prime}\right)$ spectra $(T=78 \mathrm{~K}):(-) \operatorname{PBS}\left(1,1^{\prime}\right),(+) \operatorname{PBS}\left(2,2^{\prime}\right)$, dAMP (3), "1-3-difference" (4). $\lambda_{\text {ex }}=260 \mathrm{~nm}$ (for emission spectra), $\lambda_{e m}=418 \mathrm{~nm}$ (for excitation spectra) 
incide with any separate deoxyribonucleotide fluorescence spectral band (e.g., dAMP). The spectral positions of these bands practically do not depend on the excitation wavelength (in the interval of 260-310 nm). The (-)PBS and (+)PBS bands are thought to be associated with the fluorescence of Gcomplexes (dimers and trimers formed by neighboring G-species), and/or G-complexes formed by Gspecies belong to different parts of the strand (Gintermediates). The independence of this fluorescence on the excitation wavelength in a wide spectral interval gives the ground to conclude that these complexes fluoresce not only due to the own absorption. To a great extent, this fluorescence is caused by the electronic excitation energy transfer from individual bases of the oligunucleotides. This means that these complexes are the traps of singlet excitations which are generated in individual nucleotides by light.

\subsection{Phosphorescence}

The phosphorescence spectral bands of (-)PBS (Fig. 3, line 1) and (+)PBS (Fig. 3, line 2) at $T=78 \mathrm{~K}$ are close to each other, as well as to the band of dAMP (Fig. 3, line 3) (in the interval $\lambda=370 \div 470 \mathrm{~nm})$. The difference between $(-) \mathrm{PBS} /$ $(+) \mathrm{PBS}$ and dAMP phosphorescence spectra (the band at $\lambda=530 \mathrm{~nm}$ ) is thought to be associated with an unknown center, possibly, G-complex or G-intermediate that dominates in the fluorescence. Thus, the main centers of triplet excitation capturing in (-)PBS and $(+)$ PBS oligonucleotides are A-bases and some centers of an unknown nature (possibly, G-complexes or G-intermediates, but they are not AT-complexes observed by us in [3-7]). The "1-3-difference" band was obtained by the subtraction of the dAMP spectral band from the (-)PBS spectral band.

\section{Conclusions}

The optical absorption (at $300 \mathrm{~K}$ ) and luminescence (at $78 \mathrm{~K}$ ) spectra of $(-) \mathrm{PBS}$ and $(+) \mathrm{PBS}$ oligonucleotides have been studied. Three important results have been obtained:

1. The optical absorption spectra of (-)PBS and $(+)$ PBS are not the equimolar sums of the correspondent deoxyribonucleotides spectra. The additional band at $\lambda=295 \mathrm{~nm}$ is associated with the existence of G-complexes.

2. The main centers of singlet excitation capturing in $(-) \mathrm{PBS}$ and $(+) \mathrm{PBS}$ (that are manifested in the fluorescence) are thought to be G-complexes (possibly, G-intermediates).

3. The main centers of triplet excitation capturing in $(-) \mathrm{PBS}$ and $(+) \mathrm{PBS}$ (that are manifested in the phosphorescence) are A-bases and some centers of an unknown nature (possibly, G-complexes). So, the presented data show that no AT-complexes are formed in the systems, in which $\mathrm{A}$ and $\mathrm{T}$ are not situated in neighbor positions.

We are grateful to Prof. Oleg Yeshchenko and Prof. Igor Dubey for their help.

1. S. Bourbigot, N. Ramalanjaona, C. Boudier, G.F. Salgado, B.P. Roques, Y. Mely, S. Bouaziz, N. Morellet. How the HIV-1 nucleocapsid protein binds and destabilizes the primer binding site during reverse transcription. J. Mol. Biol. 383, 1112 (2008).

2. M. Sholokh, R. Sharma, D. Shin, R. Das, O.A. Zaporozhets, Y. Tor, Y. Mely. Conquering 2-aminopurine's deficiencies: Highly emissive isomorphic guanosine surrogate faithfully monitors guanosine conformation and dynamics in DNA. J. Am. Chem. Soc. 137(9), 3185 (2015).

3. V. Yashchuk, V. Kudrya, M. Losytskyy, H. Suga, T. Ohul'chanskyy. The nature of the electronic excitations capturing centres in the DNA. J. Mol. Liq. 127 (1-3), 79 (2006).

4. V.M. Yashchuk, V.Yu. Kudrya, M.Yu. Losytskyy, I.Ya. Dubey, H. Suga. Electronic excitation energy transfer in DNA. Nature of triplet excitations capturing centers Mol. Cryst. Liq. Cryst 467, 311 (2007).

5. V.Yu. Kudrya, V.M. Yashchuk, I.Ya. Dubey, K.I. Kovalyuk, O.I. Batsmanova, V.I. Mel'nik, G.V. Klishevich, A.P. Naumenko, Yu.M. Kudrya. The spectral properties of the telomere fragments Ukr. J. Phys 61 (6), 516 (2016).

6. V.M. Yashchuk, V.Yu. Kudrya, I.Ya. Dubey, K.I .Kovalyuk, O.I. Batsmanova, V.I. Mel'nik, G.V. Klishevich. Luminescence of telomeric fragments of DNA macromolecule $\mathrm{Mol}$. Cryst. Liq. Cryst 639, 1 (2016).

7. V.M. Yashchuk, V.Yu. Kudrya. The spectral properties of DNA and RNA macromolecules at low temperatures: Fundamental and applied aspects Methods Appl. Fluoresc.5, 014001 (2017).

Received 24.06.18

В.Ю. Кудря, В.М. Ящук, А.П. Науменко,

І. Мелі, Т.В. Удод, Ю.С. Кремінсъка

СПЕКТРАЛЬНІ ВЛАСТИВОСТІ

ОДНОЛАНЦЮГОВИХ ФРАГМЕНТІВ ВІРУСНОЇ ДНК

Р е з ю м е

Представлено результати досліджень оптичного поглинання (при $300 \mathrm{~K}$ ), флюоресценції та фосфоресценції

ISSN 2071-0194. Ukr. J. Phys. 2018. Vol. 63, No. 10 
(при $78 \mathrm{~K}$ ) олігонуклеотидів (-)PBS та (+)PBS. (-)PBS являє собою ДНК-форму зв'язувальної ділянки мінуспраймеру (5'GTCCCTGTTCGGGCGCCA3') геному вірусу імунодефіциту людини першого типу (ВIЛ-1); (+)PBS

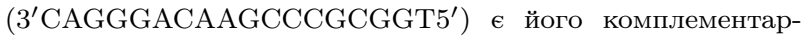
ною послідовністю. Показано, що спектри оптичного поглинання (-)PBS та (+)PBS не збігаються з відповідними еквімолярними сумами спектрів нуклеотидів, що входять до їх складу. Різниця між спектрами олігонуклеотидів та відповідними еквімолярними сумами на довжині хвилі 295 нм пов'язана з існуванням деякого стабільного комплексу між базами (можливо, G-комплексу). Спектри флюоре- сценції (-)PBS та $(+)$ PBS є близькими один до одного та до спектра флюоресценції олігонуклеотиду, дослідженого нами раніше. Смуги спектрів (-)PBS та (+)PBS пов'язані, можливо, з флюоресценцією комплексів, що проявляються в поглинанні. Спектри фосфоресценції (-)PBS та (+) PBS є близькими один до одного та до спектра dAMP (в діапазоні довжин хвиль 370-470 нм). Різницеві спектри фосфоресценції між спектром (-)PBS (а також (+)PBS) та спектром dAMP (в околі 530 нм) асоціюється нами з невідомим центром (можливо, G-комплексом). Таким чином, основними центрами захоплення триплетних збуджень у (-)PBS та $(+) \mathrm{PBS} \in$ аденінові бази та центри невідомої природи. 